The International Journal of Indian Psychology

ISSN 2348-5396 (e) | ISSN: 2349-3429 (p)

Volume 5, Issue 1, DIP: 18.01.043/20170501

DOI: $10.25215 / 0501.043$

http://www.ijip.in | October-December, 2017

Research Article

\title{
A Comparative Analysis of Forgiveness among Adolescents, Adults and Older People
}

\author{
Riffat Sadiq ${ }^{1}$, Shumaila Mehnaz ${ }^{2}$
}

\section{ABSTRACT}

The present study focused on people of three different age groups in relation to forgiveness. It was postulated that there would be a significant difference among adolescents, adults and older people in respect to forgiveness, forgiveness of self, forgiveness of others and forgiveness of situation. One hundred and fifty $(n=150)$ participants including fifty $(n=50)$ adolescents, fifty $(n=50)$ adults and fifty $(n=150)$ older people were selected through referral and respondent-driven sampling. Demographic Information Form (DIF) and Heartland Forgiveness Scale (Thompson et al., 2005) were used to collect research data. One way ANOVA test results reveal a significant difference among three groups. Older participants reported more forgiveness, forgiveness of self, others and situation than adolescents and adults. The present findings have implications for individual, family and society.

Keywords: Forgiveness, Adolescents, Adults, Older, Situation

So far scientific studies have brought different dimensions and concepts of forgiveness to surface indicating lack of consensus on a specific definition. However, moral (Murphy, 2003), religious (Rye, 2005) and psychological (Enright \& Coyley, 1998; McCullough et al., 1998) perspectives have amplified personal, familial and communal significance of forgiveness. Forgiveness is seen as willingness to foster compassion and love rather than harboring resentment and negative judgment for offenders (Enright \& Coyley, 1998). For some, forgiveness is a prosocial change in motivation, from negative to positive, towards offending partner (McCullough, Root, \& Cohen, 2006).

According to Thompson et al. (2005), forgiveness is a "framing of a perceived transgression such that one's responses to the transgressor, transgression, and squeal of the transgression are transformed from negative to neutral or positive. The source of a transgression, and therefore the object of forgiveness, may be oneself, another person, or a situation that one views as being beyond anyone’s control. It can be an illness, fate or a natural disaster”.

\footnotetext{
${ }^{1}$ Ph. D, Assistant Professor, Department of Applied Psychology, Govt. College Women University, Faisalabad, Pakistan

${ }^{2}$ Lecturer, Department of Applied Psychology, Govt. College Women University, Faisalabad, Pakistan *Responding Author
}

Received: September 02, 2017; Revision Received: October 29, 2017; Accepted: November 23, 2017 (C) 2017 Sadiq R, \& Mehnaz S; licensee IJIP. This is an Open Access Research distributed under the terms of the Creative Commons Attribution License (www.creativecommons.org/licenses/by/2.0), which permits unrestricted use, distribution, and reproduction in any Medium, provided the original work is properly cited. 
Forgiveness is, either, studied as a whole (Burnette et al., 2013), or as a set of components such as; benevolence, avoidance and revenge (McCullough, Root, \& Cohen, 2006), forgiveness of self, others and situation (Thompson et al., 2005).Forgiveness helps in reframing negative thoughts, feelings and emotions associated with offenders. For that reason, it is fairly different from pardoning, forgetting, excusing, condoning and denying (Enright \& Coyle, 1998).Negative repercussions (anger, hostility and revenge desires) associated with an offense can be effectively handled with forgiveness (Wade \&Worthington 2005). Resultantly, people can re-establish their closeness (McCullough et al., 1998).

A bulk of research evidences has highlighted forgiveness related psychological, social and familial benefits. Literature has shown forgiveness determining psychological well-being (Sadiq, 2013; Akhtar, Dalon \& Barbow, 2017). Forgiveness is positively connected with well-being (Sadiq \& Ali, 2012), whereas negatively connected with psychological distress (Orcutt, 2006). It also has significant and meaningful association with mental health (Asghari \& Roshani, 2013; Saeed, 2014), with relationship satisfaction and commitment (McCullough et al., 1998) and with personality traits (Hampto, 2015). Research also proved an association of self and other forgiveness with psychological distress (Maselko, 1998, as cited in Sadiq, 2013), with depression and anxiety (Hebl \& Enright, 1993). Depression (Berry et al., 2005), anger, depression and anxiety (Seybold et al., 2001) get decreased, if level of forgiveness is higher. Restoration of interpersonal relationship and regulation of social connectivity is possible because of forgiving (McCullough \& Witvliet, 2002). People exhibits less aggression and more sympathy, if they cherish higher forgiveness (Ross, Kendall, Matter, Wrobel \& Rye, 2004). Dispositional forgiveness also constitutes selfcontrol (DeWall, Pond, \& Bushman, 2010). Marital relations and family functioning depends on forgiveness (Fincham \& Beach, 2002). It is an essential part of conflict resolution, wellbeing, social and intimate relationships (McCullough, Root, Tabak, \& Witvliet, 2009; Van der Wal, Karremans, \& Cillessenj, 2014).

Literature, covering the role of demographics in forgiveness, documented women reporting more forgiveness that men (Miller et al., 2008). Men harbor more revenge feelings and thoughts than women (Rijavec et al., 2010). Non-working married women were more benevolent towards in-laws than working married women (Sadiq\& Ali, 2014).Duration of offense (Ling-hsuan, 2009), apology and confession (McCullough et al, 2003), relationship satisfaction (Fincham \& Beach, 2002) largely contribute to forgiving.

People of all genres believe the significance of forgiveness in everyday life, despite being unforgiving in certain situations. Each domain of life (i.e, family, education, job, community services and religion) demands positivity, tolerance and adaptability. Forgiveness is deemed as a coping method (Rasmussen \& Lopez, 2000, as cited in Thompson et al., 2005) and associated with general life adjustment (Orathinkal \& Vansteenwegen, 2006). In this regard, empirical investigation of forgiveness is the need of time. Like other demographics, age is also imperative in determining forgiveness. Thus, it has been envisioned to explore 
forgiveness and its type in the context of three distinct age groups (adolescents, adults and older people). The present study is novel and will be helpful in gaining insight that how adolescents, adults and older people behave towards self, others and situation.

\section{Objectives}

1. To examine the nature and propensity of forgiveness among general population

2. To compare the propensity of forgiveness among people of three different age groups

\section{Hypotheses}

1. There would be significant difference among adolescents, adults and old people in respect to forgiveness

2. There would be significant difference among adolescents, adults and old people in respect to forgiveness of self

3. There would be significant difference among adolescents, adults and old people in respect to forgiveness of others

4. There would be significant difference among adolescents, adults and old people in respect to forgiveness of situation

\section{METHODS}

\section{Participants}

The present study employed comparative research method whereby one hundred and fifty $(n=150)$ participants including fifty $(n=50)$ adolescents (12-18 years old), fifty $(n=50)$ adults (21-59 years old) and fifty ( $n=50)$ older people (60 years or above) were required. However, in the presents study, reported age ranges for adolescents were (14-17), for adults were (2959) and for older people were (60-87).Participants were categorized into three different independent groups while taking into account major age classifications irrespective of its subdivision (i.e, young adolescents, middle adult, young older, etc).

Entire sample was recruited applying referral and respondent-driven sampling. Equal number of male $(n=75)$ and female $(n=75)$ participants belonging to middle-class families were included in each group. Participants with physical disease (i.e, diabetes mellitus, hepatitis, cardiac problems, infertility, disability, drug addiction), with mental disorder, with the status of divorcee, widow or hailing from broken families were not recruited.

\section{Measures}

Demographic Information Form was utilized to collect basic information from the participants including age, gender, socio-economic status, marital status, educational level, number of family members, etc.

Heartland Forgiveness Scale (Thompson et al., 2005) was used to examine forgiveness among participants. It is 18 items scale comprised of three subscales; forgiveness of self (6items), forgiveness of others (6-items) and forgiveness of situation (6-items). All items of this scale are scored on 7-point of continuum that ranged from (Almost always false than true-1 to 
Almost always true of me-7).Reliability of English Version for the subscale of forgiveness of self is $(\alpha=.75)$, for forgiveness of others is $(\alpha=.78)$, for forgiveness of situation is $(\alpha=.77)$ and full scale is $(\alpha=.86)$. Obtained reliability of Urdu version of forgiveness of self is $(\alpha=.68)$, forgiveness of others is $(\alpha=.73)$, forgiveness of situation is $(\alpha=.65)$ and of total forgiveness is $(\alpha=.71)$. The scale was found to be correlated $(r=0.79)$ with other measure of forgiveness, Transgression-Related Interpersonal Motivation (TRIM- 18) indicating good convergent validity.

\section{Procedure}

The present study has been carried out with the approval from affiliated institutions. First of all, required measure (Heartland Forgiveness Scale) was translated with the approval from its authors. The scale was given to three different professionals having expertise in translating the measures in Urdu language. Then, other three experts having command on English language were given Urdu versions for back translation. In last, another seventh professional from the field of psychology, also a bilingual expert, crossed check original and translated version in order to sort out best items for final draft. Then, approved final draft in Urdu language was administered on a group $(n=50)$ to calculate its reliability.

Afterwards, participants were approached and were briefed the purpose of research, risk/benefit ratio, confidentiality of personal information (gathered using demographic information form) and their responsibility to respond to the measures. Their consent for volunteer participation was taken first. Then, participants signed the informed consent form and answered the given measures. Their responses were scored and statistically analyzed using SPSS, Version-23.0.

\section{RESULTS}

Descriptive statistics and one way ANOVA were calculated to test the hypotheses and summary of the results have been described below;

Table: 1 Descriptive statistics showing mean difference among participants

\begin{tabular}{|l|c|c|c|c|c|c|}
\hline \multirow{2}{*}{ Variables } & \multicolumn{5}{|c|}{ Groups } \\
\cline { 2 - 7 } & \multicolumn{2}{|c|}{ Adolescents } & \multicolumn{2}{c|}{ Adults } & \multicolumn{2}{c|}{ Older } \\
\cline { 2 - 7 } & $M$ & $S D$ & $M$ & $S D$ & $M$ & $S D$ \\
\hline Forgiveness & 65.14 & 11.73 & 71.32 & 9.26 & 78.88 & 10.06 \\
\hline Forgiveness of Self & 22.20 & 4.93 & 23.48 & 5.85 & 27.52 & 4.25 \\
\hline Forgiveness of Others & 22.32 & 5.71 & 24.82 & 3.81 & 26.48 & 4.99 \\
\hline $\begin{array}{l}\text { Forgiveness of } \\
\text { Situation }\end{array}$ & 20.62 & 5.15 & 23.02 & 3.59 & 24.88 & 5.30 \\
\hline
\end{tabular}

Descriptive statistics (Table: 1) reveal mean difference among groups of participants. Mean scores of older people $(M=78.88, S D=10.06)$ are greater than Adults $(M=71.32, S D=9.26)$ and adolescents $(M=65.14, S D=11.73)$ on the variable of forgiveness. Older participants also scored more on the variable of forgiveness of self $(M=27.52, \mathrm{SD}=4.25)$ than adults $(M$

(C) The International Journal of Indian Psychology, ISSN 2348-5396 (e)| ISSN: 2349-3429 (p) | 27 
$=23.48, S D=5.85)$ and adolescents $(M=22.20, S D=4.93)$. In respect to forgiveness of others, mean scores of older participants are more $(M=26.48, S D=4.99)$ as compare to adults $(M=24.82, S D=3.81)$ and adolescents $(M=22.32, S D=5.71)$. Related to forgiveness of situation, adolescents $(M=20.62, S D=5.15)$ and adults $(M=23.02, S D=3.59)$ scored less in comparison to older people $(M=24.88, S D=5.30)$.

Table: 2 Summary of one way ANOVA

\begin{tabular}{|c|c|c|c|c|c|c|}
\hline Variables & Groups & $\begin{array}{c}\text { Sum of } \\
\text { squares }\end{array}$ & $d f$ & Mean squares & $F$ & Sig \\
\hline \multirow[t]{3}{*}{ Forgiveness } & $\begin{array}{l}\text { Between } \\
\text { groups }\end{array}$ & 4735.560 & 2 & 2367.780 & 21.874 & .000 \\
\hline & Within groups & 15912.180 & 147 & 108.246 & & \\
\hline & Total & 20647.740 & 149 & & & \\
\hline \multirow{3}{*}{$\begin{array}{l}\text { Forgiveness } \\
\text { of Self }\end{array}$} & $\begin{array}{l}\text { Between } \\
\text { groups }\end{array}$ & 771.040 & 2 & 385.520 & 15.052 & .000 \\
\hline & Within groups & 3764.960 & 147 & 25.612 & & \\
\hline & Total & 4536.00 & 149 & & & \\
\hline \multirow[t]{3}{*}{$\begin{array}{l}\text { Forgiveness } \\
\text { of Others }\end{array}$} & $\begin{array}{l}\text { Between } \\
\text { groups }\end{array}$ & 438.520 & 2 & 219.260 & 9.129 & .000 \\
\hline & Within groups & 3530.740 & 147 & 24.019 & & \\
\hline & Total & 3969.260 & 149 & & & \\
\hline \multirow[t]{3}{*}{$\begin{array}{l}\text { Forgiveness } \\
\text { of Situation }\end{array}$} & $\begin{array}{l}\text { Between } \\
\text { groups }\end{array}$ & 456.120 & 2 & 228.060 & 10.104 & .000 \\
\hline & Within groups & 3318.040 & 147 & 22.572 & & \\
\hline & Total & 3774.160 & 149 & & & \\
\hline
\end{tabular}

Results (Table: 2), obtained through one-way ANOVA, have revealed a significant difference among participants of three different aged groups. It has been proved that there is a significant difference among adolescents, adults and older people in respect to forgiveness $[F(2,147)=21.874, p=.000]$, forgiveness of self $[F(2,147)=15.052, p=.000]$, forgiveness of others $[F(2,147)=0.129, p=.000]$ and forgiveness of situation $[F(2,147)=$ 10.104, $p=.000]$.

\section{DISCUSSION}

The present study has shown older people reporting more tendency to forgive self, others and situation in comparison to adolescents and adults. Whereas, adolescents seemed less forgiving towards self, other and situation than other two groups. A plausible point in favor of these findings is that adolescents are usually indulged in risk taking experiences (Scott, 2004, as cited in Karaman\&Cok,2007). They are also less likely to take adaptive decision than adults because of having less mature capacity to resist social and emotional influences (Karaman \& Cok,2007).On the other hand, older people have greater emotional well-being than younger people (Momtaz et al., 2014).Cognitive, emotional, behavioral and social

(C) The International Journal of Indian Psychology, ISSN 2348-5396 (e)| ISSN: 2349-3429 (p) | 28 
changes are driving forces for the facilitation of forgiveness (Hall \& Fincham, 2005). Due to these changes and emotional stability, older people have come up with more forgiving propensity than adolescents and adults. Through forgiving self, others and situation, they got themselves freed from negative thoughts and emotions as well.

Older people are satisfied being surrounded by family, friends, children and grandchildren. People, during this phase of life, spend most of their time in discussing family and social issues. In South Asian culture, older people are the symbol of compassion, generosity, love and affection which entails forgiving in daily life. Compassion and generosity are fostered among forgiving people (Enright, 1996). Older people also play vital role in resolving interpersonal conflicts and family disputes. Even, adolescents and adults are seen to be receiving guidance from them regarding daily issues. Their enormous life experience has meaningful lessons for others. This life style is one reason for avoiding blame, accepting self and showing contentment in life. Forgiving self is the way of restoring self-respect and selfacceptance (Dillon, 2001). It is related with self-esteem and life satisfaction also (Leach \& Lark, 2004).

Older participants of the present study scored more on the subscale of forgiveness of others, whereas adolescents scored less than others. In a previous study, older adolescents reported more resentment and willingness to seek revenge (Chiaramello et al, 2005). Among adolescents, forgiveness is conditioned with apology and remorse (Vinsonneau \& Mullet, 2001). Adolescents encounter criticism, ridicule, insult and bullying in daily life that cultivate grudge feeling regarding others. Consequently, they are less likely to forgive others. In comparison to them, older people, due to their generosity and compassion, do not wait for apology and remorse. Furthermore, their involvement in social and welfare activities strengthen their tendency to forgive others as compare to adolescents and adults.

Older participants of the present study also reported more forgiveness of situation than adolescents and adults. People, in later life, appraise life events as less stressful (Aldwin, 1991) because of decrease in social roles. Involvement is social roles constitutes hassles in daily life (Lazarus, 1991). Previous researches also have described elderly reporting less negative emotions as compare to younger individuals (Lawton, Kleban, \& Dean, 1993). Situation may instigate negative emotions, feelings and behaviors, if it violates positive assumptions pertaining to self and circumstances (Thompsons et al., 2005). When, people are unforgiving towards situation, their positive beliefs and schemas are converted into negative one, as a result, they are overwhelmed with negative emotions and thoughts. It is consistent with previous finding that forgiveness of situation predicted anger, anxiety, depression and satisfaction with life (Thompson et al, 2005). People usually do not forgive situations such as; illnesses or disaster (Enright \& Zell, 1989) rather blame Allah (God) or their fate. Perhaps, it is because of their weak religious beliefs.

In young age, people are more involved in worldly matters and avoid religious practices. On the other hand, it is commonly observed that older people are more inclined towards religion. Their religious beliefs help them in accepting the problematic situation. Having faith in Allah 
(God) and His decisions encourage people to show tolerance and patience in front of adversity. Even, natural disaster or illness is perceived as an ultimate decision from Allah (God) and as a trial for humans. For this reason, older people, being indulged in more religious practices, forgive the situation more. It is also evident by previous study that religious forgiveness predicts forgiveness of situation (Amini et al, 2014). Forgiveness is associated with religiousness (Walter, 2013) and religious faith (Edwards et al., 2002). This religiosity may also contribute to forgiveness of self and others.

The present study also has shown that, on the variable of forgiveness, mean scores of adults are more than adolescents but less than older participants. In fact, South Asian adults have more social and family responsibilities such as; bread earner (adult men), home makers (adult women), child rearing, maintaining family status and reputation. Besides, education and marriage of offspring are their sole responsibility. They are expected to take more mature decision and show adaptability to environment than adolescents. They have less social and welfare activities than older people because of being embedded with social responsibilities. Sometimes, they find less time for recreational activities, too. They might have mixed feeling, emotions and thoughts owing to the mixed and multiple responsibilities. It is the probability of reporting more forgiveness than adolescents but less forgiveness than older participants of the present study.

\section{IMPLICATIONS OF THE STUDY}

We humans, despite living in the era of advanced technology, have declined morally and socially. Today, our relationships are on edge owing to intolerance, selfishness and impatience for each other. Resultantly, interpersonal conflicts, family destruction and violence are prevalent all over the world, particularly in South Asia. Even minor conflict has become a headache. Besides, variety of situations/circumstances such as; chronic illnesses, natural disasters and painful incidents have entangled us.

With the help of forgiveness, one can combat these political, social and psychological upheavals. Forgiveness is an effective coping strategy used to deal with interpersonal offenses (Pargament, 1997). It is integral in psychological healing (Hope, 1987).Forgiveness encompasses restructuring of negative thoughts, emotions and feelings into positive one. The present study has pointed out adolescents and adults preferring less forgiveness than older people. It is time to learn from our elders to stand firm against personal and social problems. We cannot move forward if we are stuck with negative, emotions, feelings and thoughts. Adolescents and adults need to incorporate positive attributes (such as; forgiveness, tolerance, compassion) in themselves so that they could move ahead to sustain harmony and peace within family and society.

\section{LIMITATIONS AND RECOMMENDATIONS}

In the present study, three different groups were taken considering major age classification. Sub-classification such as; young adolescents, older adolescents, middle adults, oldest adults or older-older were not focused. Role of other demographics such as; gender, education, 
marriage, family system, employment status were ignored while analyzing the results. In future, researchers should focus on sub-classification and other demographics in determining forgiving attitude.

\section{Acknowledgments}

The author appreciates all those who participated in the study and helped to facilitate the research process.

Conflict of Interests: The author declared no conflict of interests.

\section{REFERENCES}

Akhtar, S., Dolan, A., \& Barlow, J. (2017).Understanding the relationship between state forgiveness and psychological wellbeing: A qualitative study. Journal of Religion and Health, 56(2): 450-463.

Aldwin, C. M. (1991). Does age affect the stress and coping process? Implications of age differences in perceived control. Journal of Gerontology: Psychological Sciences, 46:174-180.

Amini, F.,Doodman, P., Edalati, A., Abbasi, Z., Redzuan, M. (2014).A study on the relationship between religiosity and forgiveness among students. Applied Science Reports, 5(3) 131-134. DOI: 10.15192/PSCP.ASR.2014.1.3.131134

Asghari, P., \& Roshani, K. (2013).Validation of forgiveness scale and a survey on the relationship of forgiveness and students' mental health. International Journal of Psychology and Behavioral Research, 2(2): 109-115.

Berry, J. W., Worthington, E. I., Parrot, L., O’Connor, L. E., \& Wade, N. G. (2005). Forgiveness, vengeful rumination and affective traits. Journal of Personality, 73, 143.

Burnette, J.L., Davisson, E.K., Finkel, E.J., Van Tongeren, D.R., Hui, C.M., \& Hoyle, R.H. (2013). Self-Control and forgiveness: A meta-analytic review. Social Psychological and Personality Science, 5(4), 443-450.

Chiaramello, S., Mesnil, M., Sastre, M. T. M., \& Mullet, E. (2005).Dispositional forgiveness among adolescents. European Journal of Developmental Psychology,5 (3):326-337.

DeWall C. N., Pond, R. S., \& Bushman, B. J. (2010). Sweet revenge: Diabetic status as a predictor of interpersonal forgiveness. Personality and Individual Differences, 49, 823- 826.

Dillon, R.S. (2001). Self-forgiveness and self-respect. Ethics, 112, 53-83.

Edwards, L. M., Lapp-Rincker. R. H., Maygor-Moe, J. L., Rehfeldt, J. D., Ryder, J. A., Brown, J. C., \& Lopez, S. J. (2002). A positive relationship between religious faith and forgiveness: Faith in the absence of data? Pastoral Psychology,50(3): 147-152.

Enright, R.D. (1996). Counseling within the forgiveness triad: On forgiving, receiving forgiveness, and self-forgiveness. Counseling \& Values, 40(2), 107-127

Enright, R.D., \& Coyley, C.T. 1998. Researching the process model of forgiveness within psychological interventions. In M. R. McCullough, K. I. Pargament, \& C. E. Thoresen (Eds).Forgiveness: Theory, Research and Practice. New York: Guildford Press. 


\section{A Comparative Analysis of Forgiveness among Adolescents, Adults and Older People}

Enright, R. D., \& Zell, R. L. (1989) Problems encountered when we forgive one another. Journal of Psychology and Christianity, 8, 52-60.

Fincham, F. D., \& Beach, S. R. H. (2002). Forgiveness in marriage: Implications for psychological aggression and constructive communication. Personal Relationships,9, 239-251.

Hall, J. H., \& Fincham, F. D. (2005). Self-forgiveness: The stepchild of forgiveness research. Journal of Social and Clinical Psychology, 24 (5), 621-637

Hampton, L. (2015). Forgiving the Self and Others: Exploring Component Level Differences and the Effects of Personality (Undergraduate Honors Thesis).Retrieved from http://scholar.colorado.edu/

Hebl, J. H., Enright, R.D. (1993). Forgiveness as a psychotherapeutic goal with elderly females. Psychotherapy, 30, 658-667.

Hope, D. (1987). The healing paradox of forgiveness. Psychotherapy, 24: 240-244.

Karaman, N. G.,\& Cok, F. ( 2007). Adolescent risk-taking: comparison between adolescents and adults opinion. PaidÈia, 17(38), 357-364

Lawton, M. P., Kleban, M. H., \&Dean, J. (1993). Affect and age: Cross-sectional comparisons of structure and prevalence. Psychology and Aging, 8, 165-175.

Lazarus, R. S. (1991). Progress on a cognitive-motivational-relational theory of emotion. American Psychologist, 46, 819-834.

Leach, M. M., \& Lark, R. (2004). Does spirituality add to personality in the study of trait forgiveness? Personality and Individual Differences, 37, 147-156.

Ling-hsuan, T. (2009). Choosing to forgive: An experimental study of factors that affect forgiveness. Retrieved from http:// gradworks.umi.com/33/76/3376733.html.

McCullough, M. E., Rachel, K. C., Sandage, S. D., Worthington, E. L. Jr., Brown, S. W., \& Hight, T. L. (1998). Interpersonal forgiving in close relationships: II. Theoretical elaboration and measurement. Journal of Personality and Social Psychology, 75, 1586-1603.

McCullough, M. E., \&Witvliet, C. V. (2002).The psychology of forgiveness. In C. R. Snyder \& S. J. Lopez (Eds.), Handbook of positive psychology. New York, NY: Oxford University Press

McCullough, M. E., Fincham, F. D., \& Tsang, J. (2003). Forgiveness, forbearance and time: The temporal unfolding of transgression-related interpersonal motivations. Journal of Personality and Social Psychology, 84, 540-557.

McCullough, M. E., Root, L. M., \& Cohen, A. D. (2006). Writing about the personal benefits of a transgression facilitates forgiveness. Journal of Consulting and Clinical Psychology, 74, 887-897.

McCullough, M. E., Root, L. M., Tabak, B., \& Witvliet, C. V. O. (2009).Forgiveness. In S. J. Lopez (Ed.), Handbook of positive psychology. New York, NY: Oxford

Miller, A.J., Worthington, E.L.Jr., \& McDaniel, M.A. (2008). Gender and forgiveness: A Meta-analytic review and research agenda. Journal of Social and Clinical Psychology, 27(8), 843-876. 


\section{A Comparative Analysis of Forgiveness among Adolescents, Adults and Older People}

Momtaz, Y. A., Hamid, T. A., \& Ibrahim, R. (2014). Cohort comparisons: emotional wellbeing among adolescents and older adults. Clinical Intervention in Aging,9: 813-819. DOI: $10.2147 / C I A . S 61636$

Murphy, J. G. (2003). Getting Even: Forgiveness and its Limits. NewYork: Oxford University Press.

Oranthinkal, J., \&Vansteenwegen, A. (2006).The effects of forgiveness in marital satisfaction in relations to marital stability. Contemporary Family Therapy, 28 (2), 251-260.

Orcutt, H. K. (2006). The prospective relationship of interpersonal forgiveness and psychological distress symptoms among college women. Journal of Counseling Psychology, 53(3), 350-361. DOI: 10.1037/0008-400x.40.1.1.1

Pargament, K. I. (1997). The Psychology of Religion and Coping: Theory, Research and Practice. New York: Guilford Press.

Rijavec, M., Jurcec, L., \& Mijocevic, I. (2010).Gender differences in the relationships between forgiveness and depression/happiness. Psychological Topics, 19(1): 180-202.

Ross, S. R., Kendall, A. C., Matters, K. G., Rye, M. S., \& Wrobel, T. A. (2004). A personological examination of self- and other-forgiveness in the five factor model. Journal of Personality Assessment, 82, 207- 214

Rye, M. S. (2005). The religious path towards forgiveness. Mental Health, Religion and Culture, 8, 205-215.

Sadiq, R., \& Ali, A, Z. (2012). Forgiveness and its relationship with well-being among married women in joint family. Pakistan Journal of Clinical Psychology, 11(1): 5968.

Sadiq, R. (2013). Forgiveness as a Predictor of Psychological Well-being, Life Satisfaction and Marital Adjustment in Married Adult Women (Doctoral dissertation).Institute of Clinical Psychology, University of Karachi, Pakistan.

Sadiq, R., \& Ali, A. Z. (2014).Forgiving in-law: A comparison among working and nonworking married women. Asian Academic Research Journal of Social Sciences and Humanities, 1(23): 503-514.

Saeed, N. (2014). Relationship of Forgiveness with Mental Health in Adult (graduate thesis).Department of Psychology, University of Gujrat, Gujrat- Pakistan.

Seybold, K. S. Hill, P. C., Neumann, J. K., \& Chi, D. S. (2001).Physiological and psychological correlates of forgiveness. Journal of Psychology and Christianity, 20, 250-259.

Thompson, L. Y., Synder, C. R., Hoffman, L., ...,\& Roberts, D. E. (2005). Dispositional forgiveness of self, other and situation. Journal of Personality, 73, 313-359.

Van der Wal, R. C., Karremans, J. C., \&Cillessenj, A. H. N. (2014).It takes two to forgive:

The Interactive role of relationship value and executive control. Personality and Social Psychology Bulletin, 40(6).

Retrieved from http://journals.sagepub.com/doi/abs/10.1177/0146167214525807

Vinsonneau, G., \& Mullet, E. (2002). Willingness to forgive among young adolescents: A comparison between two groups of different cultural origins living in France. International Journal of Group Tensions, 30 (3): 267-278. 
A Comparative Analysis of Forgiveness among Adolescents, Adults and Older People

Wade, G.N., \&Worthington, L. E. (2005).In search of common core: A content analysis of interventions to promote forgiveness. Psychotherapy: Theory, Research, Practice Training, 42(2):160-177. doi: 10.1037/0033-3204.42.2.160.

How to cite this article: Sadiq R, \& Mehnaz S (2017). A Comparative Analysis of Forgiveness among Adolescents, Adults and Older People. International Journal of Indian Psychology, Vol. 5, (1), DIP: 18.01.043/20170501, DOI: 10.25215/0501.043

(C) The International Journal of Indian Psychology, ISSN 2348-5396 (e)| ISSN: 2349-3429 (p) | 34 